\title{
Control of Digitaria insularis resistant to glyphosate using a combination of herbicides in coffee farms
}

\author{
Luís Carlos Onofre $^{1}$ (D), Thiago Borba Onofre ${ }^{2}$ iD Tiago Teruel Rezende $^{1}$ (D)
}

${ }^{1}$ Universidade José do Rosário Vellano/UNIFENAS, Departamento Agronomia, Alfenas, MG, Brasil ${ }^{2}$ University of Florida, Department of Agricultural and Biological Engineering, Gainesville, FL, USA Corresponding author: Ic.o@hotmail.com, thiagoborba90@gmail.com, tiago.rezende@unifenas.br Received in July 11, 2020 and approved in January 5, 2021

\begin{abstract}
Coffee has a significant economic, social, and cultural impact on Brazilian society, generating jobs for thousands of Brazilians. Good management practices such as weed control have direct and indirect benefits on coffee yield and quality. Currently, there is an increase in the infestation rate of Digitaria insularis in coffee plantations due to chemical resistance to glyphosate. In the literature, the study of the combination of glyphosate with different herbicides has been investigated, aiming at improving the efficiency of the control of $D$. insularis. The objective of this work was to evaluate the efficiency of control of the $D$. insularis in a coffee farm using a combination of glyphosate with clethodim and phenoxaprope-p-ethyl. Trials were conducted in a commercial coffee farm in southern Minas Gerais in a field with a two-year-old cultivar IAC Catuaí 144. The experiment was conducted under a completely randomized design with five treatments and four replications, totaling 20 experimental plots. Thirty and ninety days after application, the number of plant were counted. The results show that the use of glyphosate alone was not efficient to control of $D$. insularis. The results show that the herbicide mixtures were efficient in the control.
\end{abstract}

Key words: Chemical control; Herbaceous; Weeds; Mixtures; Active ingredients; Coffea arabica.

\section{INTRODUCTION}

The success of agri-business and coffee production is directly related to good management practices, rational use of natural, financial, technological resources with the aim of increasing yield and quality of production (Caixeta; Guimarães; Romaniello, 2008). As coffee is a perennial crop, the competition for limited resources such as light, water, and nutrients with weeds reduces yield and quality.

Effective weed control is vital to guarantee a healthy crop (Ronchi; Silva, 2006). Weed can be controlled with three techniques: manually, with machines, or with chemical herbicides (Melloni et al., 2013). Due to the practicality and reduction of labor, chemical herbicides are one of the great technological advances of the 20th century in agriculture. The use of chemical herbicides allows weed control even during rainy periods where mechanical control is not efficient (Werlang; Silva; Ferreira, 2005).

Despite the great advantage of using herbicides over manual methods, one of the major problems in modern agriculture is the resistance of weeds to chemical herbicides. The resistance of plants to chemical herbicides is an evolutionary process that occurs due to the combination of intensive use with low dose (Prado; Jorrín; Garcia-torres, 1997; Duke, 1996; Valverde, 2007). Since the dose is not enough for efficient control, weeds gradually become chemically resistant to chemical control, and resistant plants become dominant.

Carvalho et al. (2011), Christoffoleti et al. (1994), and Machado et al. (2006) identified the existence of biotypes of Digitaria insularis chemically resistant to the herbicide glyphosate. The D. insularis is a perennial, herbaceous, upright species, with striated stems and between 50 and $100 \mathrm{~cm}$ high. In adulthood, the $D$. insularis forms clumps from short rhizomes and reproduces by seeds. Seeds of $D$. insularis have good germinative power and are covered by many hairs and carried by the wind over great distances, quickly spreading D. insularis biotypes resistant to glyphosate. According to Carvalho et al. (2011) plants of D. insularis chemically resistant to glyphosate absorbs the herbicide more slowly, it has less translocation, and it has a faster metabolization of the active ingredient. Carvalho et al. (2011) also observed resistance to glyphosate in $D$. insularis plants with only three to four leaves.

The combination of foliar herbicides with different active ingredients has been an alternative to increasing the efficiency of chemically resistant $D$. insularis (Barroso et al., 2014). In addition to the combination of different active principles, the efficiency of chemical control has been investigated in different phenological phases. Barroso et al. (2014) combined clethodim and phenoxaprope-p-ethyl and found the efficiency of control of chemically resistant $D$. insularis in early phenological stages was better than for resistant bitter grass in an advanced stage of development. However, Barroso et al. (2014) observed that the mixtures with herbicides of similar active ingredients are not always efficient.

Based on the above literature review, the objective of this work is to evaluate if the mixture of glyphosate with phenoxaprope-p-ethyl and clethodim would improve the 
efficiency of control of $D$. insularis in a coffee field in Conceição da Aparecida, Minas Gerais, Brazil.

\section{MATERIAL AND METHODS}

The experiment was executed from April 2019 to July 2019 in a coffee farm in Conceição da Aparecida (21 4'59' S, 46 13 '46" O), Minas Gerais, Brazil. The coffee farm was selected due to a suspect of the infestation of $D$. insularis resistant to glyphosate. The coffee field is two years old and the variety is the IAC Catuaí 144 coffee (Coffea arabica L.), the rows are three meters wide and the plant's distance is one meter from each other. There is a total of 3,3 thousand plants per hectare and the elevation of the farm is 960 meters above the sea. The experiment was designed using a randomized block design with five treatments and four replicates (Table 1). Each plot consisted of a segment of a row with a length of 10 meters and an area of $600 \mathrm{~m}^{2}$ per plot.

Table 1: Treatments and herbicides doses used in this experiment.

\begin{tabular}{ccc}
\hline & Treatment & Dose L.ha ${ }^{-1}$ \\
\hline T0 & Control & - \\
T1 & glyphosate $^{1}+$ phenoxaprop-p-ethyl $^{3}$ & $3+1$ \\
T2 & glyphosate $^{1}+$ clethodim $^{2}$ & $3+1$ \\
& & \\
T3 & glyphosate + phenoxaprop-p-ethyl $^{3}+$ clethodim $^{2}$ & $3+0.5+$ \\
& & 0.5 \\
T4 & glyphosate $^{1}$ & 3 \\
\hline
\end{tabular}

Herbicides: ${ }^{1}$ Roundup Original ${ }^{\circledR},{ }^{2}$ Select ${ }^{\circledR},{ }^{3}$ Podium ${ }^{\circledR}$.

Thirty days before the start of the experiment, all plots were mowed using a trimmer (model FS 220 Stihl), and on the day of the herbicide application, the weeds were approximately $20 \mathrm{~cm}$ tall in all plots. The herbicides were applied on the morning of April 18, 2019, using a 16-liter electric sprayer (Super Agri, Brotas, SP), with a constant pressure of 60 PSI, nozzle fan-04, with a spray volume of 300 L.ha ${ }^{-1}$.

Thirty Days After the Application (DAA) of the herbicides, using a $1 \mathrm{~m}^{2}$ metal frame placed at the center of each plot, the number of $D$. insularis plants were counted and then collected for dry matter analysis. At 90 DAA, the number of $D$. insularis plants were re-counted.

The number of plants counted with 30 and 90 DAA and dry matter from samples collected at 30 DAA, were subjected to analysis of variance, using the $F$ test at 5\% significance. Observed data of weight, number of plants at 30 and 90 DAA were transformed to $\sqrt{50+x}$ to satisfy the requistes of the analysis of variance. The Scott-knott at 5\% confidence of interval was applied for the test of means. R software, version 3.2.3 (R Core-Team 2015) was used for statistical analysis.

\section{RESULTS}

D. insularis dry matter collected at 30 Days After the Application (DAA) from treatments is shown in Figure 1. As in can be seen in Figure1, all treatments, including the treatment with the herbicide glyphosate, reduced $D$. Insularis dry matter in comparison to the control treatment.

The number of $D$. insularis plants counted 30 and 90 DAA of the herbicides are shown in Figure 2 and 3, respectively. All treatments, besides control T0, reduced the number of $D$. insularis plants at $30 \mathrm{DAA}$, as shown in Figure 2. Moreover, herbicide mixture treatments (T1, T2, and T3) were statistically significantly different at 5\% from treatment T4 (glyphosate) and control.

At 90 DAA, Figure 3, the number of plants in treatments with a mixture of herbicides (T1, T2, and T3) were significantly different at 5\% from the treatments $\mathrm{T} 4$ and $\mathrm{T} 0$. It is important to observe that for $\mathrm{T} 1, \mathrm{~T} 2$, and $\mathrm{T} 3$, the number of plants decreased, and as it can be noted that there no $D$. insularis left on T2. On the other side, T4 did not show an increase in the overall number of plants, but the standard error increased significantly.

\section{DISCUSSION}

If we were to consider only the dry-biomass analysis at 30 Days After Application (DAA) (Figure 1) and the visual image (Figure 4B), we would conclude that all treatments were efficient to control Digitaria insularis. However, as found by Zobiole et al. (2016), herbicides treatments can be significantly different from the control, but not all herbicide treatments are efficient in controlling Digitaria insularis.

The number of plant analysis at 30 and 90 DAA, Figure 2 and Figure 3, respectively, and the visual analysis at 90 DAA $4 \mathrm{C}$, and 4D confirm that glyphosate (T4) only was not able to efficiently control the $D$. insularis infestation. Barroso et al. (2014) found that glyphosate combined with other herbicides is a necessary step for effective control of Digitaria insularis. In this work, the combinations of glyphosate with clethodim (T2), and glyphosate with phenoxaprop-p-ethyl and clethodim (T3) yielded the best results.

Although future work is necessary to confirm, our results indicate that there is a high chance that the $D$. insularis present in this coffee farm is chemically resistant to glyphosate. 


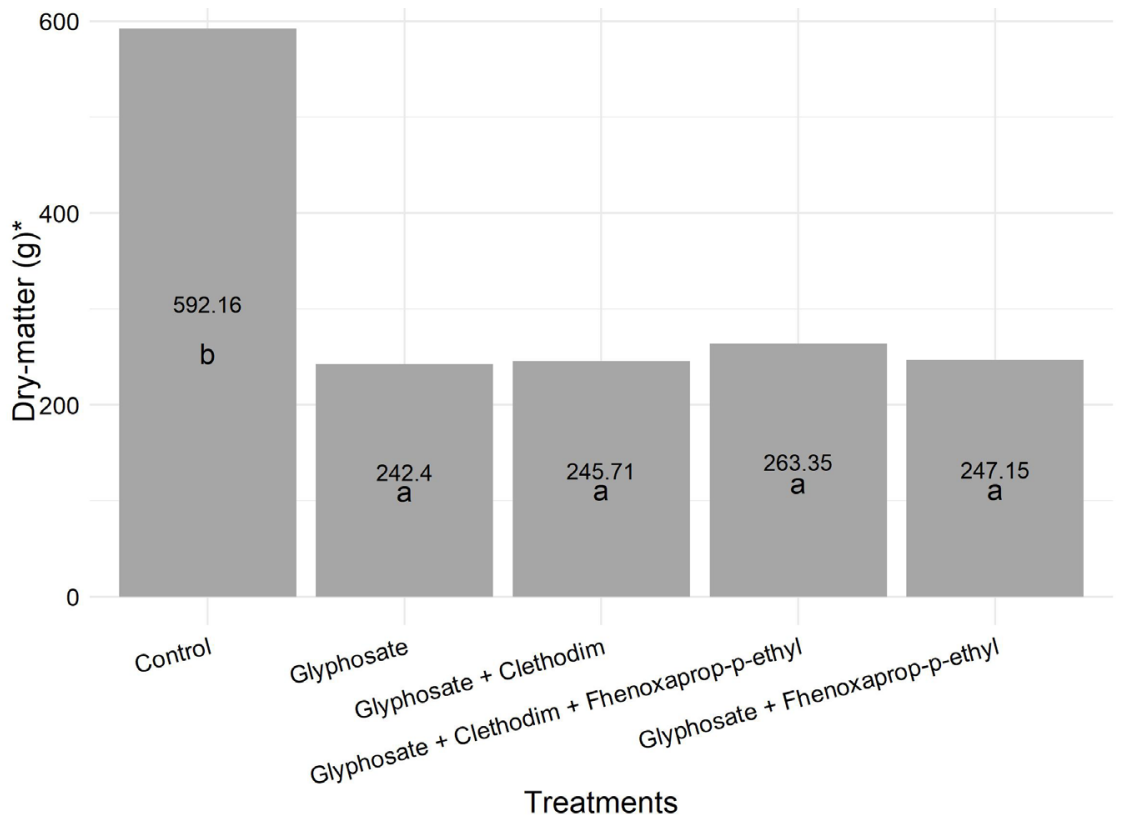

Figure 1: Dry-matter of Digitaria insularis at 30 DAA.

*Original mean, however the data was transformed for the variance and Scott-Knott tests. Mean value followed by the same letter do not differ according to the Skott-Knott test at 5\%. CV: $17.44 \%$.

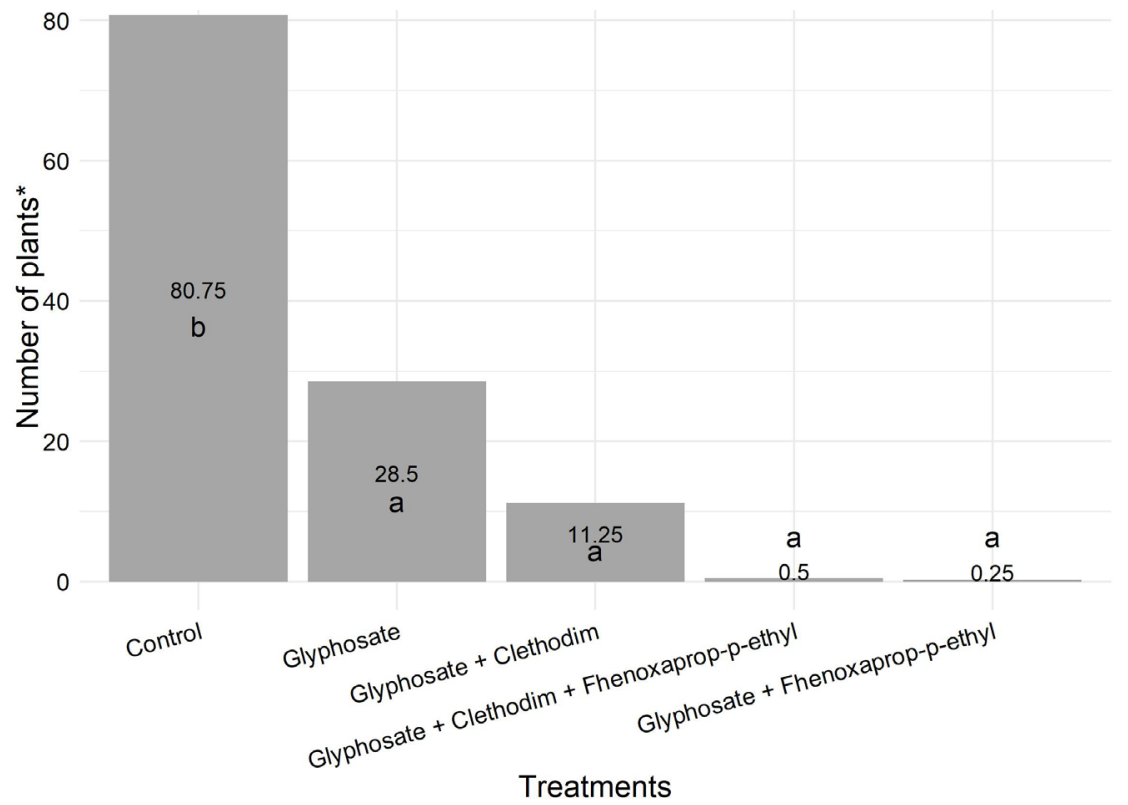

Figure 2: Number of $D$. insularis at 30 DAA. CV: $13.77 \%$.

*Original mean, however the data was transformed for the variance and Scott-Knott tests. Mean value followed by the same letter do not differ according to the Skott-Knott test at $5 \%$. 


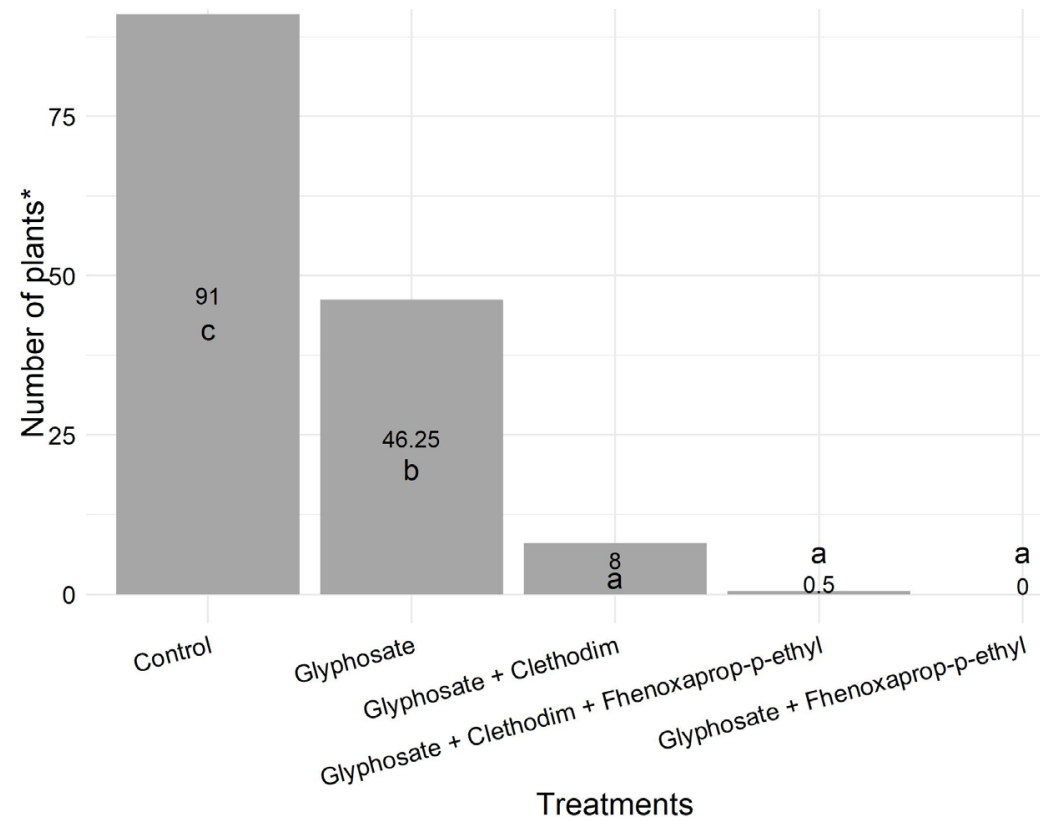

Figure 3: Number of $D$. insularis at 90 DAA. CV: $15.55 \%$.

*Original mean, however the data was transformed for the variance and Scott-Knott tests. Mean value followed by the same letter do not differ according to the Skott-Knott test at 5\%.
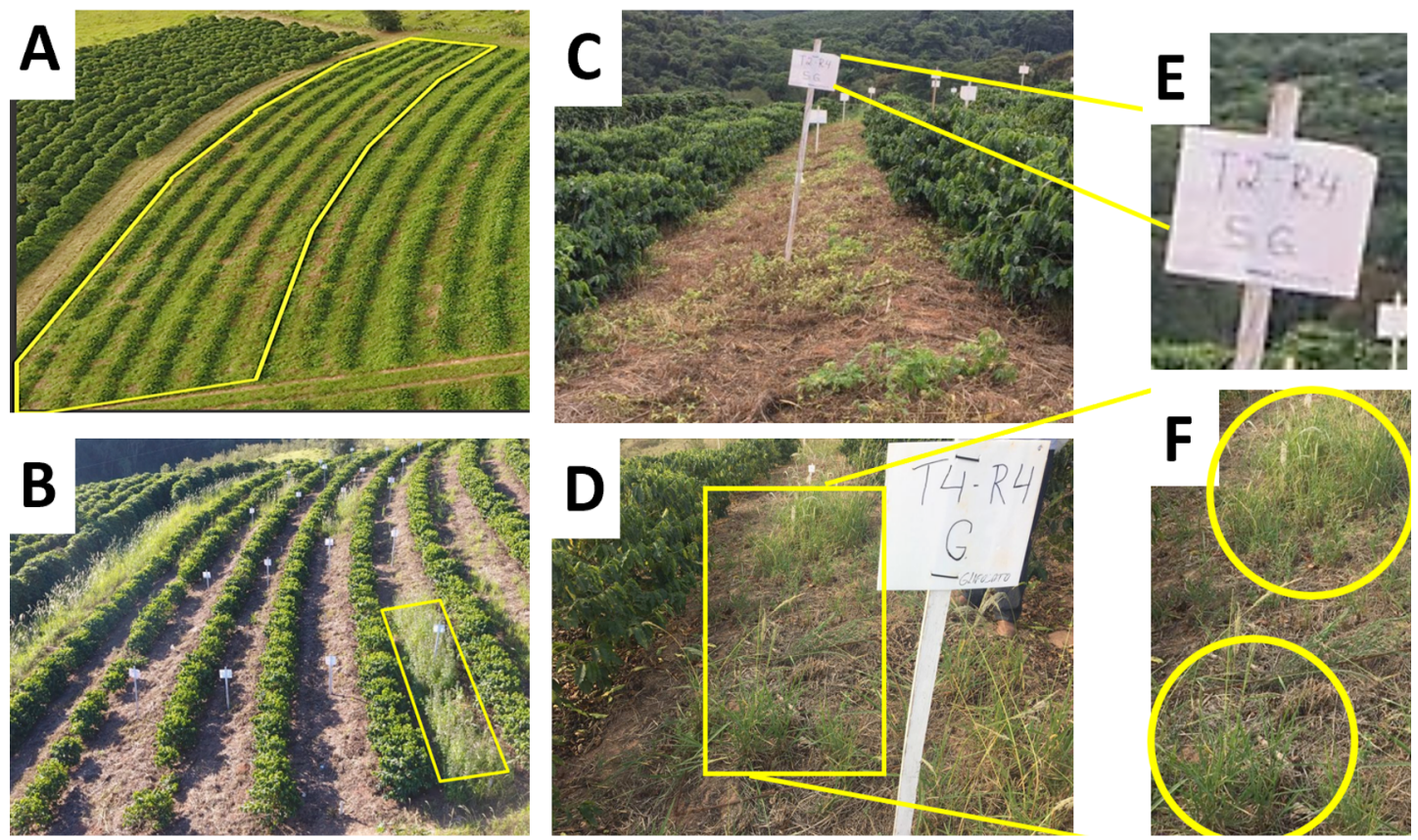

Figure 4: Visual analysis of the experiment. A) Aerial image of the experiment area. B) Aerial image at 30DAA. C) Treatment T2 (glyphosate and phenoxaprop-p-ethyl) at 90 DAA. D) Treatment T4 (glyphosate) at 90 DAA. E) and F) are zoom-ins of T2 and T4, respectively. 


\section{CONCLUSIONS}

In this work, the combination of glyphosate with different herbicides was investigated, and the results indicate that the mixture of glyphosate with clethodim and glyphosate combined with phenoxaprop-p-ethyl and clethodim were efficient in suppressing the infestation of $D$. insularis in coffee farms.

\section{REFERENCES}

BARROSO, A. A. et al. Interaction between ACCaseinhibiting herbicides and different glyphosate formulations to control bitter grass. Planta Daninha, 32(3):619-627, 2014.

CAIXETA, G. Z. T.; GUIMARÃES, P. T. G.; ROMANIELLO, M. M. "Management as a way to guarantee the competitiveness of coffee production." Informe Agropecuário, 29(244):14-23, 2008.

CARVALHO, L. B. et al. Detection of sourgrass (Digitaria insularis) biotypes resistant to glyphosate in Brazil. Weed Science, 59(2):171-176, 2011.

CHRISTOFFOLETI, P. J.; FILHO, R. V.; SILVA, C. B. Plant resistance to weeds against herbicides. Planta Daninha, 12(1):13-20, 1994.

CORE-TEAM, R. A language and environment for statistical computing. $R$ Foundation for Statistical Computing. 2015. Available in: http://www.R-project. org. Access in: February, 08, 2021.
DUKE S. O. Will herbicide resistance ultimately benefit agriculture? Weed and Crop Resistance to Herbicides. Springer, Dordrecht. p.323-331. 1996.

MACHADO, A. F. L. et al. Análise do crescimento de digitaria insularis. Planta Daninha, 24(4):641-647, 2006.

MELLONI, R. et al. Métodos de controle de plantas daninhas e seus impactos na qualidade microbiana de solo sob cafeeiro. Revista Brasileira de Ciencia Do Solo, 37(1):66-75. 2013.

PRADO, R.; JORRÍN, J.; GARCIA-TORRES, L. Weed and crop resistance to herbicides. Springer Science \& Business Media. 1997. 340p.

RONCHI, C. P.; SILVA, A. A. "Efeito na competição de plantas daninhas sobre o crescimento de plantas jovens de café.” Planta Daninha, 24(3):415-423, 2006.

WERLANG, R. C.; SILVA, A. A. da; FERREIRA, L. R. Efeito de diferentes formulações de glyphosate no manejo de plantas daninhas na cultura do cafeeiro. Revista Brasileira de Herbicidas, 4(1):1-8, 2005.

VALVERDE, B. E. Status and management of grass-weed herbicide resistance in Latin America. Weed Technology, 21:310-23. 2007.

ZOBIOLE, L. H. S. et al. Controle de capim-amargoso perenizado em pleno florescimento. Revista Brasileira de Herbicidas, 15(2):157-164, 2016. 